\title{
Results of Long-Term Human Growth Hormone Therapy for: Pituitary Dwarfism
}

\author{
KaZuo SHIZUME, Fukashi MATSUZAKI, Minoru IRIE, and NaKaAKi OSAWA \\ Department of Endocrinology and Endocrine Research Laboratory, \\ Toranomon Hospital, Minato-ku, Tokyo and Third Department of Internal \\ Medicine, University of Tokyo Faculty of Medicine, Hongo, Tokyo
}

\begin{abstract}
Synopsis
Since 1961, 14 patients with pituitary dwarfism were treated with human growth hormone (HGH). In this report, the result of long term treatment for more than 2 and a half years in five patients is reported. The dose of $\mathrm{HGH}$ was $2-4 \mathrm{mg}$ three times a week. In the first six months, a marked increase in height was observed in all cases. The increase declined gradually and in some cases HGH became almost ineffective. In such cases antiHGH antibody was observed in the patient's blood. Bone age/height age progress ratio was less than one in most cases. No side effect was observed except pain at the site of injection. In two cases, height reached to the level above- $2 \sigma$ of the height of normal adult.
\end{abstract}

It has been generally recognized that human growth hormone (HGH) has the effect to facilitate growth in cases of pituitary dwarfism. As of April 1970, however, there are only 33 reported cases in the world in which $\mathrm{HGH}$ has been administered for more than two years (Soyka et al., 1970). We have treated 14 cases of pituitary dwarfism with $\mathrm{HGH}$, and observed initial increases in growth rate in all cases. In two of the cases the therapy became practically ineffective after several months, whereas in the other twelve it remained effective for more than one year. Some of these cases were previously reported (Shizume, 1968; 1969). The present paper reports the results on five of the above-mentioned twelve cases in which $\mathrm{HGH}$ therapy has been continued for more than three years.

\section{Method}

In this study, height age was based on the average height and standard deviation for each age shown in 1967 School Health Statistics compiled by the Statistics Section of the Ministry of Education (age in these statistics is in terms of whole years as of April 1; for

Received for publication September 14, 1970. example, a group "ten years old" includes children ranging from exactly ten years of age to ten years and 364 days; in our data, the average height for the age of ten chronological years represents the calculated mean of the figures (or the ages of nine and ten shown in the Ministry of Education staistics), and bone age was estimated by comparing radiographs of the left hand and wrist with the standards of Greulich and Pyle (1950). The HGH used had been extracted from acetone-fixed human pituitary glands by the Raben method (1962).

\section{Results}

\section{Case 1 N. K., female (Fig. 1)}

At the time of initial diagnostic evaluation (in April, 1965) the patient was $72 / 12$ years old, $102.1 \mathrm{~cm}$ high (height age four years), and weighed $16 \mathrm{~kg}$. Her bone age was 6 $9 / 12$ years. From infancy she had been slow in height and weight growth, PBI at the age of eight to ten months being 2.0-2.5 $\mathrm{\gamma} / \mathrm{d} l$. Administration of desiccated thyroid began when she was about ten months old and continued for about one year, failed to increase the rate of height growth. Her mental and intellectual growth was normal. At the age of about $32 / 12$ years she began to take $5 \mathrm{mg}$ 


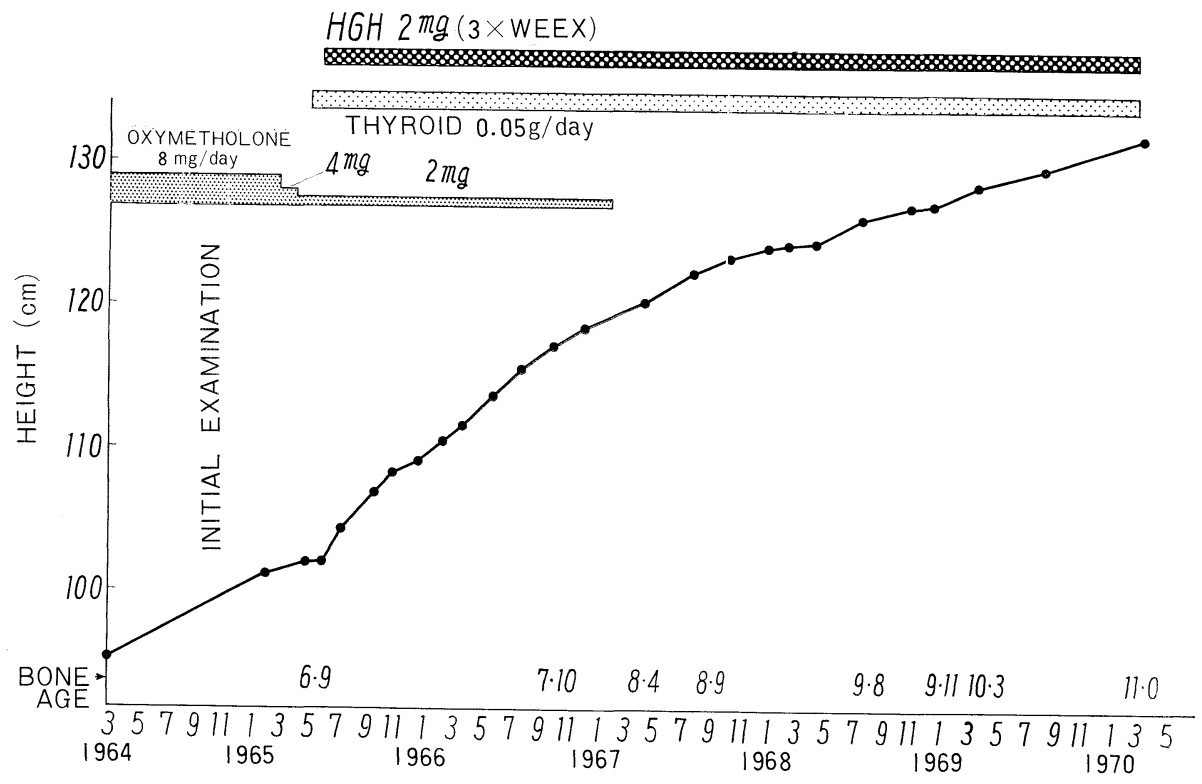

Fig. 1. Growth Curve for N. K.

of oxymetholone (Anadorol) daily. Thereafter the dose was increased at the rate of $1 \mathrm{mg}$ every year, and from six years old onward she had been receiving $8 \mathrm{mg} /$ day. The height gain during the preceding one year had been $6.2 \mathrm{~cm}$. Endocrine function tests conducted at that time gave the following results:

$\begin{array}{ll}\text { PBI } & 3.2 \gamma / \mathrm{d} l \\ { }^{131} \mathrm{I}_{-} \mathrm{T}_{3} \text { resin uptake } & 28 \% \\ { }^{131} \mathrm{I}_{2} \text { 24-hr uptake } & 2.3 \% \\ \text { Fasting blood glucose } & 51 \mathrm{mg} / \mathrm{d} l \\ \text { Serum cholesterol } & 210 \mathrm{mg} / \mathrm{d} l \\ \text { Serum phosphorus } & 2.1 \mathrm{mg} / \mathrm{d} l \\ \text { Urinary 17-OHCS } & 1.6 \mathrm{mg} / \text { day }\end{array}$

From her clinical symptoms, fasting blood sugar level, and the serum phosphorus level, she was diagnosed as a case of pituitary dwarfism due to $\mathrm{GH}$ and TSH deficiencies Considering that her bone age by far exceeded her height age, the dose of oxymetrone was reduced since the beginning of May 1965, and from May 29th $2 \mathrm{mg}$ of $\mathrm{HGH}$ was adminstered intramuscularly 3 times a week. Later it became possible to determine the blood $\mathrm{GH}$ level of this patient by radioimmunoassay and in April 1966, GH secretion test was conducted with insulin-induced hypoglycemia. In all blood samples, GH level was less than 0.25 $\mathrm{m} \mu \mathrm{g} / \mathrm{m} l$, and no response of increased $\mathrm{GH}$ secretion was observed. This result confirmed the diagnosis of pituitary dwarfism.

With HGH administration, her height measured every six months has shown successive increases of $6.7 \mathrm{~cm}, 4.7 \mathrm{~cm}, 4.5 \mathrm{~cm}, 3.1$ $\mathrm{cm}, 2.9 \mathrm{~cm}, 1.7 \mathrm{~cm}, 1.6 \mathrm{~cm}, 1.6 \mathrm{~cm}$, and $2.3 \mathrm{~cm}$. As of March, 1970 (age 12 1/12 years). she was $132.0 \mathrm{~cm}$ high (height age ten years). Since the average height of normal females 12 $1 / 12$ years old is $144.9 \mathrm{~cm}$ and the standard deviation $(\sigma), 6.7 \mathrm{~cm}$, the height of our patient is now above $-2 \sigma$ of the level of the average height for her age, or $131.5 \mathrm{~cm}$. During the $49 / 12$ years of HGH therapy, her bone age has increased $43 / 12$ years. In January 1970 (after 4 6/12 years of HGH therapy), her blood was checked for $\mathrm{HGH}$ antibodies by radioimmunoassay and the presence of antibody was observed.

Case 2 S. O., male (Fig. 2)

At the time of initial diagnostic evaluation 


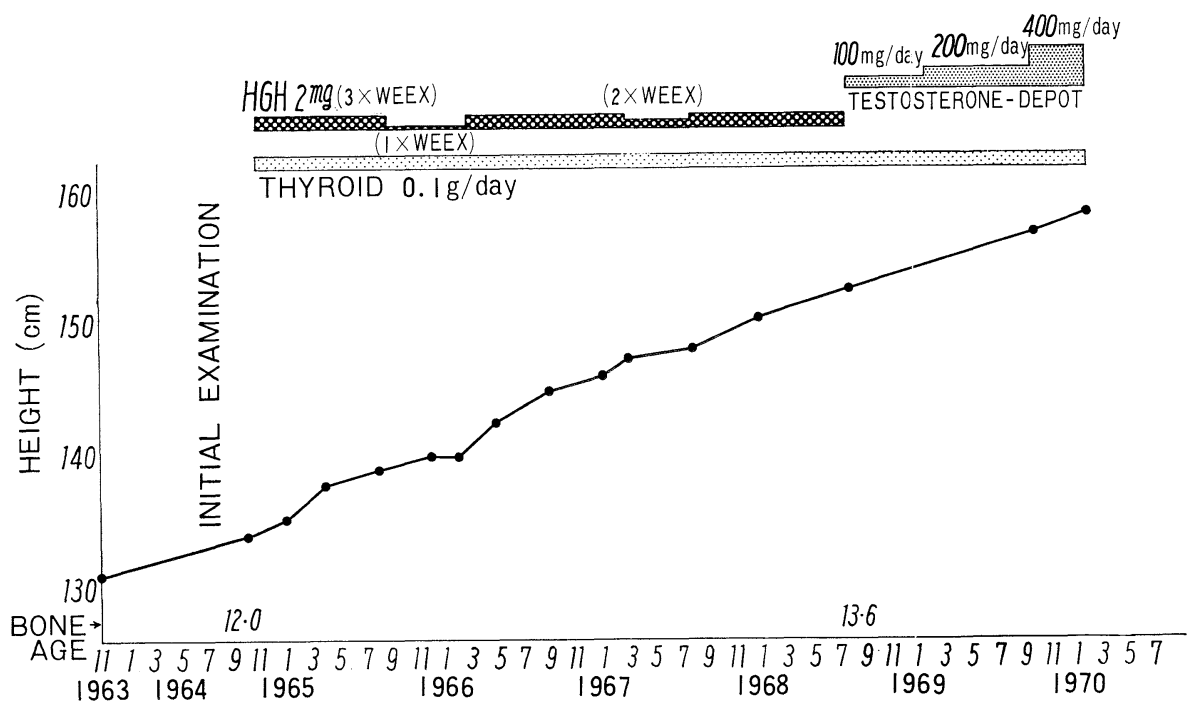

Fig. 2. Growth Curve for S. O.

(in September, 1964) the patient was $141 / 12$ years old, $134.0 \mathrm{~cm}$ high (height age $105 / 12$ years). His bone age was 12 years. No secondary sex characteristics were observed. At the age of about seven years he began to show a marked decline in growth rate. When he was nine years old, his pituitary was extirpated due to craniopharyngioma. Although methyltestosterone was administered intermittently thereafter, he grew only about $2 \mathrm{~cm}$ a year. Initial tests gave the following results:

Thyroid function tests:

$\begin{array}{ll}{ }^{131} \mathrm{I} \text { 24-hr uptake } & 8.5 \% \\ { }^{131}{\mathrm{I}-\mathrm{T}_{3} \text { resin uptake }} & 16.4 \% \\ \text { Serum cholesterol } & 294 \mathrm{mg} / \mathrm{d} l\end{array}$

Adrenocortical function tests:
17-OHCS
$0.64 \mathrm{mg} /$ day
17-KS
$1.9 \mathrm{mg} /$ day

Blood cortisol (morning) $2.9 \gamma / \mathrm{d} l$

Posterior pituitary function: polyuria, negative; specific gravity of urine, 1.017

From these results impairment in TSH, $\mathrm{ACTH}$, and GTH secretion were noted. In 1966, injection of HGH was suspended for a week and GH secretion tests were performed with insulin hypoglycemia and intravenous administration of arginine. In none of the blood samples was it possible to demonstrate the presence of $\mathrm{GH}$, indicating that the patient was unable to secrete $\mathrm{GH}$.

Since November, 1964, 2 mg of HGH was administered three times a week. The patient grew $4.1 \mathrm{~cm}$ in the first six months and $1.0 \mathrm{~cm}$ in the next five months. Subsequently, with the frequency of injections reduced to once a week, he failed to show any increase in height for six months. In March, 1966 the three times a week schedule was resumed, and in the following twelve months the patient grew by $7.2 \mathrm{~cm}$. Later, the schedule was changed to twice a week and the growth rate declined again, to $0.6 \mathrm{~cm}$ in 5 months. Finally, the frequency of injection was brought back to three times a week, and he grew $4.8 \mathrm{~cm}$ in one year. In August, 1968 (age, 17 6/12 years), he was $152.8 \mathrm{~cm}$ high, and weighed $45 \mathrm{~kg}$. The average height of males at this age is $166.4 \mathrm{~cm}$ and the standard deviation $(\sigma), 5.5 \mathrm{~cm}$. Therefore, $-2 \sigma$ of the average height is $155.4 \mathrm{~cm}$, and the patient was still below the level of $-2 \sigma$ of average height. With continued $\mathrm{HGH}$ administration he may have exceeded this level. However, because of the lack of the material, $\mathrm{HGH}$ therapy was discontinued and replaced 


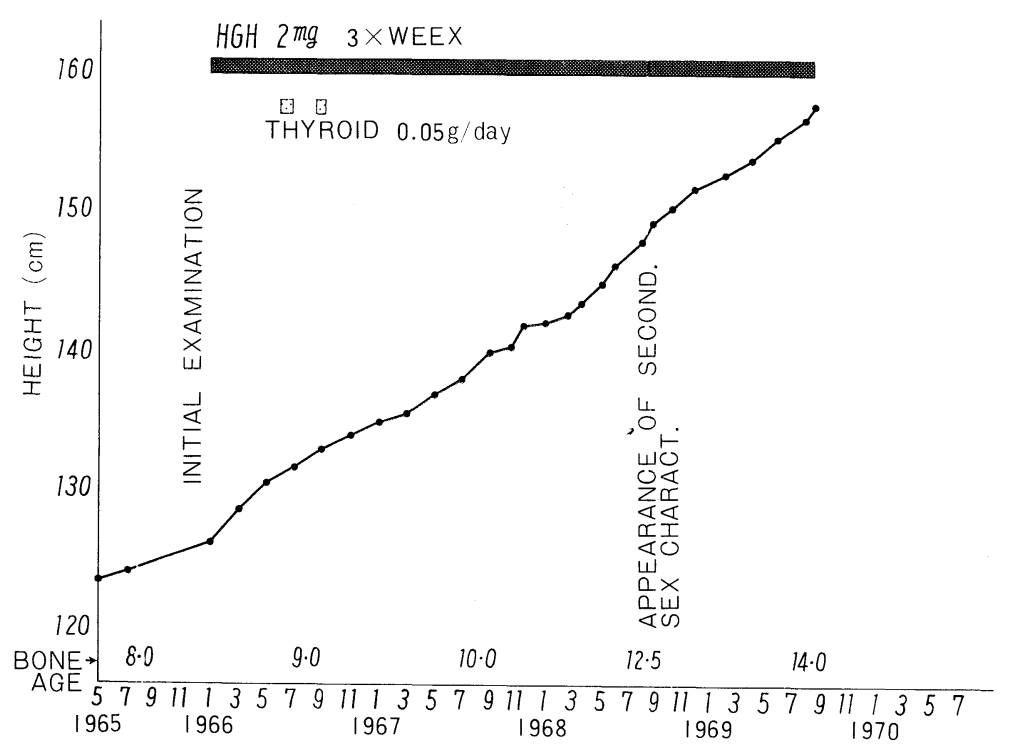

Fig. 3. Growth Curve_for T. M.

with androgen. For one year seven months, the patient has grown by $5.7 \mathrm{~cm}$, and now reached to $158.5 \mathrm{~cm}$.

\section{Case 3 T. M., male (Fig. 3)}

At the time of initial diagnostic evaluation (in January, 1966) the patient was $126 / 12$ years old, $126 \mathrm{~cm}$ high (height age, 8 10/12 years), and weighed $22.5 \mathrm{~kg}$. His bone age was 8 years. In the preceding six months he had grown by $1.0 \mathrm{~cm}$. No secondary sex characteristics were observed, nor were there any symptoms of diabetes insipidus. Endocrine function tests gave the following results:

Adrenocortical function tests:

ACTH test

Morning (before intravenous injection) (plasma cortisol) $\quad 6.3 \gamma / \mathrm{d} l$

$30 \mathrm{~min}$ (plasma cortisol) $62.6 \mathrm{\gamma} / \mathrm{d} l$

$60 \mathrm{~min}$ (plasma cortisol) $26.8 \gamma / \mathrm{d} l$

Oleesky test: Normal

Gonadal function tests:

Urinary 17-KS: Undeterminable (level too low)

Thyroid function tests:
${ }^{131}$ I 24-hr uptake
$8.8 \%$

$$
\begin{array}{ll}
\text { PBI } & 7.5 \gamma / \mathrm{d} l \\
{ }^{131} \mathrm{I}_{-} \mathrm{T}_{3} \text { resin uptake } & 32.3 \%
\end{array}
$$

Growth hormone secretion test (insulin hypoglycemia)

$\begin{array}{lcl} & \text { Blood sugar } & \text { Serum GH } \\ \text { Before test } & 110 \mathrm{mg} / \mathrm{d} l & 0.25 \mathrm{~m} \mu \mathrm{g} / \mathrm{m} l \\ 30 \mathrm{~min} & 64 \mathrm{mg} / \mathrm{d} l & 1.0 \mathrm{~m} \mu \mathrm{g} / \mathrm{m} l \\ 60 \mathrm{~min} & 50 \mathrm{mg} / \mathrm{d} l & 0.25 \mathrm{~m} \mu \mathrm{g} / \mathrm{m} l\end{array}$

From these data it was concluded that the secretion of $\mathrm{ACTH}, \mathrm{TSH}$, and $\mathrm{ADH}$ were normal and the secretion of GH was deficient whereas it was impossible to determine whether the secretion of GTH was deficient or not (since the patient might had been before adolescence). In January 1966, 2 mg of HGH started to be administered intramuscularly three times a week. During the first six months with this therapy the patient grew $5.4 \mathrm{~cm}$, and in the subsequent six-month period $3.4 \mathrm{~cm}, 3.2$ $\mathrm{cm}, 4.0 \mathrm{~cm}, 5.0 \mathrm{~cm}$ (meanwhile secondary sex characteristics developed), and $4.4 \mathrm{~cm}$, respectively. In August 1969 (16 2/12 years old) his height was $158 \mathrm{~cm}$ (height age 14 4/12 years). Since the average height of normal males $162 / 12$ years old is $163.5 \mathrm{~cm}$ and the standard deviation $(\sigma)$ was $5.8 \mathrm{~cm}$, the patient 
was above the level of $-\sigma$ of the average height. His voice changed around August 1968, and subsequently pubic hair developed. In August 1968, urinary 17-KS was $4.7 \mathrm{mg}$ / day. Therefore this case may be considered as pituitary dwarfism due to isolated GH deficiency, and it is likely that his height growth in the second and subsequent years with $\mathrm{HGH}$ therapy was partly due to the effect of androgen.

\section{Case 4 R. M., female (Fig. 4)}

At the time of initial diagnostic evaluation (in August, 1967) the patient was $72 / 12$ years old, $98 \mathrm{~cm}$ high (height age, $33 / 12$ years), and weighed $16 \mathrm{~kg}$. Her bone age was 1 10/12 years. In the preceding eight months she had grown by only $1.5 \mathrm{~cm}$. The endocrine function tests gave the following results:

Thyroid function tests:

$$
\begin{array}{ll}
\text { PBI } & 2.5 \% / \mathrm{d} l \\
\mathrm{~T}_{3^{-}}{ }^{131} \mathrm{I} \text { resin uptake } & 19.6 \% \\
{ }^{131} \mathrm{I} \text { 24-hr uptake } & 15.6 \%
\end{array}
$$

Adrenocortical function tests:

$$
{ }^{1-24} \mathrm{ACTH} \text { test }
$$

Morning (before injection) (plasma corti$\begin{array}{ll}\text { sol) } & 9.1 \mathrm{\gamma} / \mathrm{d} l \\ 30 \mathrm{~min} \text { (plasma cortisol) } & 25.6 \mathrm{\gamma} / \mathrm{d} l \\ 60 \mathrm{~min} \text { (plasma cortisol) } & 35.2 \mathrm{\gamma} / \mathrm{d} l\end{array}$

Growth hormone secretion test: (insulin hypolycemia)

Blood sugar Serum growth

hormone

Before $72 \mathrm{mg} / \mathrm{d} l \quad$ Less than test

$30 \mathrm{~min} 13 \mathrm{mg} / \mathrm{d} l$

$60 \mathrm{~min} 15 \mathrm{mg} / \mathrm{d} l$

$90 \mathrm{~min} 41 \mathrm{mg} / \mathrm{d} l$

Ditto

$0.25 \mathrm{~m} \mu \mathrm{g} / \mathrm{d} l$

Ditto

Ditto

Posterior pituitary function: Polyuria, negative; specific gravity of urine, 1.018

From these data this case was diagnosed as pituitary dwarfism due to GH and TSH deficiency. Since September, 1967, 0.05 g/day of desiccated thyroid was administered for two months, but during this two-month period the patient grew only $0.5 \mathrm{~cm}$. Since November, 1967, 2 mg of HGH started to be administered intramuscularly three times per week. In the first six months with this therapy she grew by $7.5 \mathrm{~cm}$, and in the subsequent two

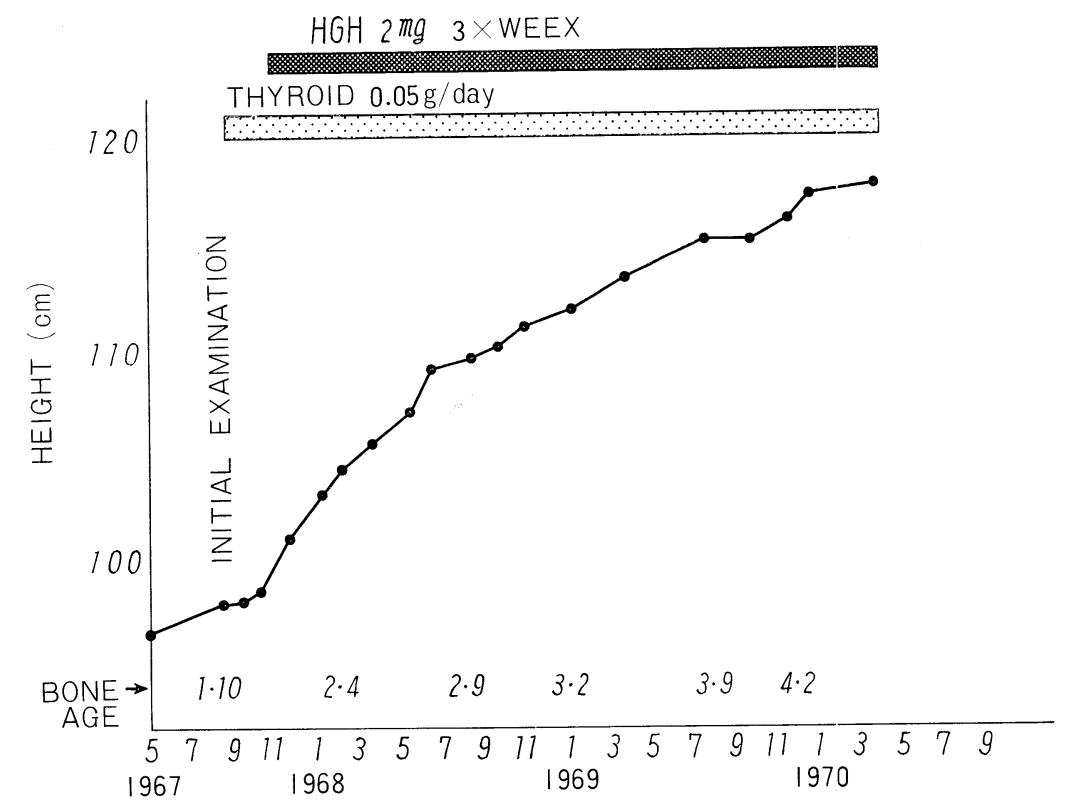

Fig. 4. Growth Curve for R. M. 
six-month periods $4.6 \mathrm{~cm}$ and $3.0 \mathrm{~cm}$, respectively. During the two-month summer vacation, in which injections became irregular, her height showed little growth. With regular injections between October and December, she again grew $2.1 \mathrm{~cm}$. Although the injection schedule was subsequently continued, her growth rate again declined sharply, with practically no gain for the first three months of 1970. In the future, we are planning to increase the dose to $4 \mathrm{mg}$. As of March 1970 , she is $99 / 12$ years old, and $117.6 \mathrm{~cm}$ high (height age $74 / 12$ years). Since the average height of females $99 / 12$ years old is $127.3 \mathrm{~cm}$ and the standard deviation $(\sigma), 5.7$ $\mathrm{cm}$, the patient is above the level of $-2 \sigma$ of average height, or $115.9 \mathrm{~cm}$. Her bone age has increased $24 / 12$ years through the $24 / 12$ years of HGH administration. In January 1970 (after 2 1/12 years of HGH administration), her blood was checked by radioimmunoassay for $\mathrm{HGH}$ antibodies, and the presence of antibody was observed.

\section{Case 5 M. S., female (Fig. 5)}

At the time of intial diagnostic evaluation (in December 1962) the patient was $117 / 12$ years old, $118.0 \mathrm{~cm}$ high (height age $78 / 12$ years), and weighed $21 \mathrm{~kg}$. Her bone age was 7 10/12 years. No secondary sex characteristics were observed, nor were there any symptoms of diabetes insipidus. Tests conducted at that time gave the following results:

$\begin{array}{ll}\text { PBI } & 3.5 \mathrm{\gamma} / \mathrm{d} l \\ \text { Serum cholesterol } & 272 \mathrm{mg} / \mathrm{d} l \\ \text { Serum phosphorus } & 4.0 \mathrm{mg} / \mathrm{d} l \\ \text { Urinary 17-OHCS } & 2.2 \mathrm{mg} / \mathrm{day}\end{array}$

She was kept under observation without treatment for two months, during which she grew by only $0.5 \mathrm{~cm}$. Therefore, beginning on March 28, 1963, 2 mg of HGH was adminestered intramuscularly three times a week, concurrently with a daily dose of $0.1 \mathrm{~g}$ of desiccated thyroid. Later it became possible to determine the blood $\mathrm{GH}$ level of this patient by radioimmunoassay. In April 1966, HGH therapy was suspended for a week, then HGH secretion in response to insulin hypoglycemia was examined. Although sufficient hypoglycemia was noted, the serum GH level could not be determined before or after the tests. Around the same time ${ }^{1-24} \beta$ ACTH was administered intravenously, and the plasma cortisol level was measured. Fasting plasma cortisol level was normal and reaction to ACTH was good. Even in April 1970, when the patient was $1811 / 12$ years old, no secondary sex characteristics were noted. Hence it

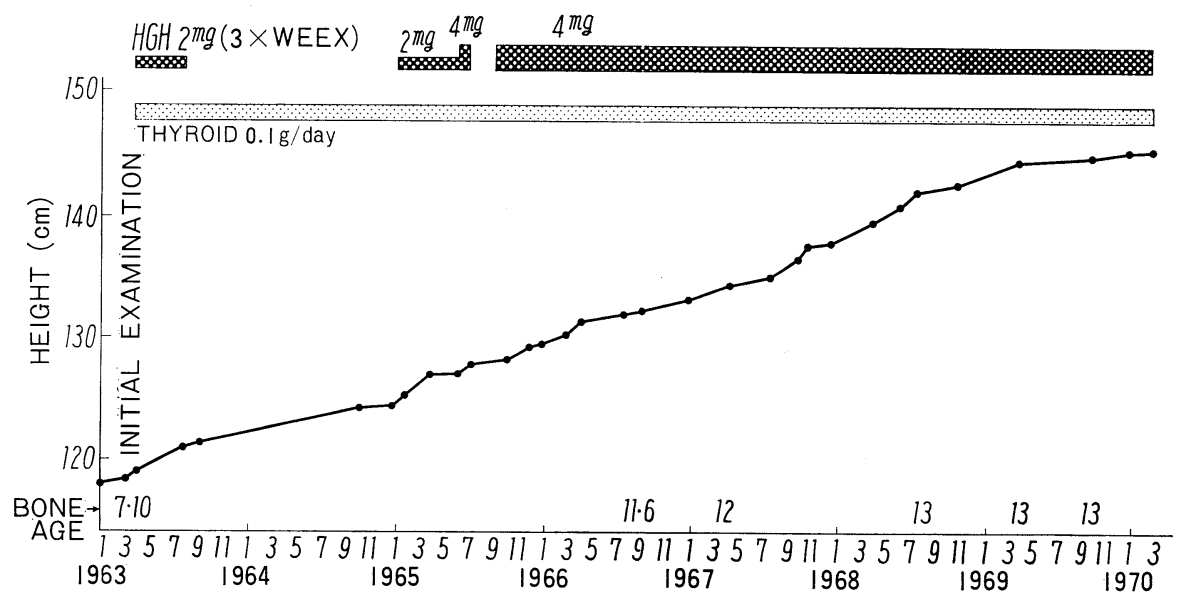

Fig. 5. Growth Curve for M. S. 
seems certain that the secretion of gonadotropic hormones was at a low level. From these results this case was considered as a pituitary dwarfism in which secretion of GH, TSH, and GTH are impaired whereas ACTH secretion is normal.

In this case, HGH therapy has produced the results shown in Figure 5. Initial $\mathrm{HGH}$ administration for four months resulted in a height gain of $2.0 \mathrm{~cm}$. (During this period, the patient was not receiving injections regularly). Later she refused to get injections of $\mathrm{HGH}$ due to the pain at the site of injection, and for one and a half years until January 1965 she was only taking desiccated thyroid orally. Meanwhile she grew by only $3.5 \mathrm{~cm}$ (at the rate of $1.2 \mathrm{~cm}$ per six months). HGH therapy was resumed in January, 1965, and for five months $2 \mathrm{mg}$ of $\mathrm{HGH}$ was injected intramuscularly three times a week. In the first three months the patient grew $2.5 \mathrm{~cm}$, but in the subsequent period of two months practically no gain in height was observed (conceivably because the patient was not receiving injections regularly). Beginning in June 1965, the dose was increased to $4 \mathrm{mg}$ each time. A height gain of $0.8 \mathrm{~cm}$ per month was observed until the schedule of injection was interrupted by a summer vacation tour made by the patient. It was resumed in September, 1965, and since then 4-mg has been admin' istered intramuscularly three times a week, although the patient has often failed to receive injections, sometimes only once a week. Meanwhile, her height measured every six months has shown successive increases of $2.6 \mathrm{~cm}, 0.9 \mathrm{~cm}, 1.7 \mathrm{~cm}, 2.0 \mathrm{~cm}, 3.0 \mathrm{~cm}, 3.4$ $\mathrm{cm}, 1.6 \mathrm{~cm}, 0.3 \mathrm{~cm}$, and $0.5 \mathrm{~cm}$. By the end of December, 1969 (chronologic age, 19 6/12 years), she was $145.3 \mathrm{~cm}$ high (height age, 12 $1 / 12$ years). Since the average height of females $186 / 12$ years old is $154.5 \mathrm{~cm}$ and the standard deviation $(\sigma), 5.1 \mathrm{~cm}$, our patient was now 1 $\mathrm{cm}$ above the level of $-2 \sigma$ of average height, or $144.3 \mathrm{~cm}$.

Her bone age was 7 10/12 years in January, 1963 , but reached to 13 years by July, 1968, increasesing $54 / 12$ years in $57 / 12$ years. Roughly there was a bone age gain of one year per calendar year. Practically no increase was observed between July, 1968 and October, 1969 , presumably because no secondary sex characteristics developed.

In January, 1970 (6 9/12 years after HGH therapy was started), the patient's blood was checked by radioimmunoassay for $\mathrm{HGH}$ antibodies, but the presence was not observed.

The data in these five cases are summarized in Table 1. Although in Case 1, 2, 4, and 5, thyroid hormone was administered almost concurrently with the administration of $\mathrm{HGH}$, the promotion of growth in these cases cannot be attributed to the direct effect of thyroid hormone because of the following reasons. In Case 1, administration of desiccated thyroid for about one year beginning at the age of 10 months had no growth promoting effect. In Case 3, at the period when $\mathrm{HGH}$ administration was only once a week, the patient failed to show any increase in height even though he was receiving desiccated thyroid. In Case 4, when only dessicated thyroid was administered for 2 months before the administration of $\mathrm{HGH}$, no significant growth promotion was observed. In Case 5, when the patient was taking only desiccated thyroid, she grew by only $3.5 \mathrm{~cm}$ in one and a half years, which was a usual height increase in pituitary dwarfism. Therefore the growth promotion in these cases can be attributed mainly to the effect of $\mathrm{HGH}$ although it is conceivable that concurrent administration of thyroid hormone contributed to some extent to the effect of $\mathrm{HGH}$. As seen from the table, patients treated with $\mathrm{HGH}$ early in their lives, such as Case 1 (N. K.) and Case 4 (R. M.), tend to show increase in height age by far exceeding their chronologic age increases. In Case 3 (T. N.), also height age has increased much faster than chronologic age, although, as previously noted, this growth may have been partly due to the secretion of androgen accompanying the development of secondary sex characteristics. In Case 2 and 5, there have 
Table 1. Height age and bone age increases through HGH therapy

\begin{tabular}{|c|c|c|c|c|}
\hline Patient & & Before therapy & After therapy & Increase \\
\hline 1. N. K. & age & $74 / 12 \mathrm{yr}$ & $121 / 12 \mathrm{yr}$ & $49 / 12 \mathrm{yr}$ \\
\hline & $\begin{array}{l}\text { Height age } \\
\text { Bone age }\end{array}$ & $\begin{array}{l}4 \text { yr }(102.1 \mathrm{~cm}) \\
69 / 12 \mathrm{yr}\end{array}$ & $\begin{array}{l}10 \mathrm{yr}(132.0 \mathrm{~cm}) \\
11 \mathrm{yr}\end{array}$ & $\begin{array}{l}6 \mathrm{yr}(29.9 \mathrm{~cm}) \\
43 / 12 \mathrm{yr}\end{array}$ \\
\hline 2. S. O. & $\begin{array}{l}\text { age } \\
\text { Height age } \\
\text { Bone age }\end{array}$ & $\begin{array}{l}14 \quad 1 / 12 \mathrm{yr} \\
105 / 12 \mathrm{yr}(134.0 \mathrm{~cm}) \\
12 \mathrm{yr}\end{array}$ & $\begin{array}{lr}17 & 10 / 12 \mathrm{yr} \\
13 & 6 / 12 \mathrm{yr}(152.8 \mathrm{~cm}) \\
13 & 6 / 12 \mathrm{yr}\end{array}$ & $\begin{array}{ll}3 & 9 / 12 \mathrm{yr} \\
3 & 1 / 12 \mathrm{yr}(18.8 \mathrm{~cm}) \\
1 & 6 / 12 \mathrm{yr}\end{array}$ \\
\hline 3. T. M. & $\begin{array}{l}\text { age } \\
\text { Height age } \\
\text { Bone age }\end{array}$ & $\begin{array}{l}12 \text { 6/12 yr } \\
8 \text { 10/12 yr }(126 \mathrm{~cm}) \\
8 \mathrm{yr}\end{array}$ & $\begin{array}{ll}16 & 2 / 12 \mathrm{yr} \\
14 & 4 / 12 \mathrm{yr}(158.0 \mathrm{~cm}) \\
12 & 6 / 12 \mathrm{yr}\end{array}$ & $\begin{array}{ll}3 & 6 / 12 \mathrm{yr} \\
5 & 6 / 12 \mathrm{yr}(32.0 \mathrm{~cm}) \\
4 & 6 / 12 \mathrm{yr}\end{array}$ \\
\hline 4. R. M. & $\begin{array}{l}\text { age } \\
\text { Height age } \\
\text { Bone age }\end{array}$ & $\begin{array}{cc}7 & 2 / 12 \mathrm{yr} \\
3 & 3 / 12 \mathrm{yr}(98 \mathrm{~cm}) \\
1 & 10 / 12 \mathrm{yr}\end{array}$ & $\begin{array}{ll}9 & 9 / 12 \mathrm{yr} \\
7 & 4 / 12 \mathrm{yr}(117.6 \mathrm{~cm}) \\
4 & 2 / 12 \mathrm{yr}\end{array}$ & $\begin{array}{ll}2 & 7 / 12 \mathrm{yr} \\
4 & 1 / 12 \mathrm{yr}(19.6 \mathrm{~cm}) \\
2 & 4 / 12 \mathrm{yr}\end{array}$ \\
\hline 5. M. S. & $\begin{array}{l}\text { age } \\
\text { Height age } \\
\text { Bone age }\end{array}$ & $\begin{array}{rr}11 & 7 / 12 \mathrm{yr} \\
7 & 8 / 12 \mathrm{yr}(118.0 \mathrm{~cm}) \\
7 & 10 / 12 \mathrm{yr}\end{array}$ & $\begin{array}{l}18 \text { 6/12 yr } \\
12 \text { 2/12 yr }(145.3 \mathrm{~cm}) \\
13 \mathrm{yr}\end{array}$ & $\begin{array}{ll}6 & 11 / 12 \mathrm{yr} \\
4 & 4 / 12 \mathrm{yr}(27.3 \mathrm{~cm}) \\
5 & 2 / 12 \mathrm{yr}\end{array}$ \\
\hline
\end{tabular}

been more increases in chronologic age than in height age, presumably because $\mathrm{HGH}$ has not been administered regularly. The bone age/height age progress ratio is $51 / 72=0.71$ in Case $1,18 / 37=0.49$ in Case $2,54 / 66=$ 0.82 in Case $3,28 / 49=0.57$ in Case 4 , and $62 / 52=1.19$ in Case 5. In other words, the progress of bone age has been slower than that of chronologic age in Case 1 through 4 . The situation is reversed in Case 5, probably because the patient has not regularly been receiving $\mathrm{HGH}$ injections, while thyroid hormone has been administered continuously.

The six-month height increases in each case are shown in Table 2. In the first six months they all showed remarkable increases, averag- ing $5.9 \mathrm{~cm}$ (Case 5 is not included as the patient was not receiving injections regulary). The average increase then declined gradually, to $4.2 \mathrm{~cm}$ in the second six-month period, 3.8 $\mathrm{cm}$ in the third, and $3.4 \mathrm{~cm}$ in the fourth.

With respect to the dosage and frequency of injection, administration of $2 \mathrm{mg}$ three times a week has been the general rule. A once or twice a week schedule, as used in Case 2, does not appear to be very effective. In Case 5, a 2-mg dose seemed to be practically ineffective, and was replaced by an increased dose of $4 \mathrm{mg}$, which proved effective.

No untoward effects have been observed except the pain at the site of injection.

Table 2. Six-months height gains with HGH therapy

\begin{tabular}{lcccccccccc}
\hline Patient & $\begin{array}{c}\text { Before } \\
\text { therapy }\end{array}$ & $\begin{array}{c}1-6 \\
\text { month }\end{array}$ & $\begin{array}{c}7-12 \\
\text { months }\end{array}$ & $\begin{array}{c}13-18 \\
\text { months }\end{array}$ & $\begin{array}{c}19-24 \\
\text { months }\end{array}$ & $\begin{array}{c}25-30 \\
\text { months }\end{array}$ & $\begin{array}{c}31-36 \\
\text { months }\end{array}$ & $\begin{array}{c}37-42 \\
\text { months }\end{array}$ & $\begin{array}{c}43-48 \\
\text { months }\end{array}$ & $\begin{array}{c}49-54 \\
\text { months }\end{array}$ \\
\hline N. K. & $3.1 \mathrm{~cm}$ & 6.7 & 4.7 & 4.5 & 3.1 & 2.9 & 1.7 & 1.6 & 1.6 & 2.3 \\
S. O. & 1.0 & 4.1 & - & 4.7 & 2.5 & - & 2.4 & 2.4 & & \\
T. M. & 1.0 & 5.4 & 3.4 & 3.2 & 4.0 & 5.0 & 5.0 & 4.4 & 4.4 & 1.8 \\
R. M. & 1.0 & 7.5 & 4.6 & 3.0 & 4.2 & 1.2 & & & & \\
M. S. & 1.5 & $3.0 ?$ & 5.0 & $2.6 ?$ & $0.9 ?$ & $1.7 ?$ & $2.0 ?$ & $3.0 ?$ & $3.4 ?$ & $1.6 ?$ \\
Average & & 5.9 & 4.2 & 3.8 & 3.4 & & & & & \\
\hline
\end{tabular}




\section{Discussion}

Various authors already reported that long-term HGH therapy is effective in pituitary dwarfism (Soyka et al., 1970). They agree, however, that the effect is marked initially, but gradually declines somewhat. Table 3 shows their data with ours. In all reports, the patients' growth in height limited to 2 to $4 \mathrm{~cm}$ a year before therapy; in the first year with $\mathrm{HGH}$ administration they grow by about 10 $\mathrm{cm}$, and subsequently they continue to grow at the rate of 6 to $9 \mathrm{~cm}$ a year.

Regarding the dose and frequency of injection of $\mathrm{HGH}$, our experience has suggested that a once or twice a week injection schedule is inadequate. According to Soyka et al. (1970), there is no significant difference in effect between administering $6 \mathrm{mg}$ a week in daily 1-mg doses and in three 2-mg doses, but administering all $6 \mathrm{mg}$ in a single weekly dose is less effective. Raben (1968) also reported that it is best to administer $2 \mathrm{mg}$ intramuscularly three times a week, and that a 1-mg dose administered three times a week suffices if the patient weighs less than 40 pounds. Soyka et al. (1968) reported that, if the rate of growth with $\mathrm{HGH}$ decreases to less than 6 $\mathrm{cm}$ a year, the effectiveness of the therapy can be restored by increasing the dose to $4 \mathrm{mg}$. In our experience, the growth rate dropped below $6 \mathrm{~cm} / \mathrm{yr}$ in the fourth year in Case 1, in the third year in Case 2, and after $21 / 2$ years in Case 4. Therefore, increased doses will be used in Cases 1 and 4 to see how they will affect the growth rates. Such decrease of effect has been considered to be partly due to the formation of $\mathrm{HGH}$ antibodies. Since their presence has been demonstrated in three of our cases, it is conceivable that antibodies are responsible for the phenomenon. Soyka et al. (1970) have suggested that HGH becomes less effective with the loss of stored fat, and facilitates height growth more effectively when sufficient stored fat is present, that is, when the subject is taking sufficient calorie and gaining weight.

Two types of $\mathrm{HGH}$ antibody formation are considered. In the first type, antibody develops usually during the first year of therapy, and tends to inhibit the growth promoting and anabolic effects of $\mathrm{HGH}$; in the second, low level of antibody appears and does not appear to seriously impair continued responsiveness. Tanner and Whitehouse (1967) reported the appearance of the first type of antibody in four out of 16 cases and Prader et al. (1967) in eight out of 18 cases, whereas Raben (1968) and Soyka et al. (1970) did not recognize the first type of antibody in their cases. It has been suggested that whether or not antibody formation of the first type occurs depends on the purity of $\mathrm{HGH}$; the less pure it is, the more likely to produce antibody. (Soyka et al., 1970). In our two cases in which antibodies have been discovered, increased doses of $\mathrm{HGH}$ will be used to see their effect on the growth rates of the patients.

The bone age/height age progress ratio is

Table 3. Height gains with $\mathrm{HGH}$ therapy in various reports

\begin{tabular}{|c|c|c|c|c|}
\hline Authors & No. of cases & 1st year & 2nd year & 3rd year \\
\hline Raben (1962) & 1 & $9.4 \mathrm{~cm}$ & 5.9 & \\
\hline Seip et al. (1966) & 4 & Av. 10.3 & Av. 6.5 & Av. 5.4 \\
\hline Prader et al. (1967) & 7 & Av. 7.2 & Av. 6.2 & \\
\hline \multirow[t]{3}{*}{ Tanner et al. (1967) } & 1 & 5.7 & 5.7 & 6.7 \\
\hline & 1 & 12.6 & 9.0 & 9.3 \\
\hline & 1 & 15.7 & 11.4 & 7.2 \\
\hline Soyka (1970) & 18 & Av. 9.0 & Av. 8.4 & Av. 7.0 \\
\hline Present series & 5 & Av.10.1 & Av. 7.2 & \\
\hline
\end{tabular}


less than 1 in the four cases in which the patient received $\mathrm{HGH}$ injections regulary. If one excludes Case 3, whose bone age was apparently facilitated by the natural development of secondary sex characteristics, and Case 1, in which anabolic steroid was concurrently used initially, the ratio is only about 0.5 , suggesting that $\mathrm{HGH}$ is not effective in promoting bone age, as various authors have already reported.

No untoward effects have been observed in our cases with the exception of pain at the injection site. In this respect we agree with other authors, who reported no particular side effects. Despite the antibody formation in some cases, no allergic reaction has been reported.

\section{References}

Greulich, W. W., and S. I. Pyle, (1950). Radiographic Atlas of Skeletal Develop- ment of the Hand and Wrist. Stanford Univ. Press.

Prader, A., M. Zachman, J. R. Poley, R. Illig, and J. Szeky, (1967). Herv Paediat Acta 32, 423.

Raben, M. S., (1962). New Engl. J. Med. 266, 82.

Raben, M. S., (1968). Clinical effects of growth hormone, in Astwood and Cassidy: Clinical Endocrinology II, Grune and Stratton, New York, London p. 69.

Seip, M. and O. Trygstad, (1966). Acta Paediat. Scand. 55, 287.

Shizume, K. (1968). Folia Endocrinol. Japon. 44, 1001. (in Japanese)

Shizume, K. (1969). Shoni Igaku 2, 169. (in Japanese)

Soyka, L. F., H. H. Bode, J. D. Crawford and F. J. Flynn, Jr. (1970). J. Clin. Endocrinol. 30, 1.

Tanner, J. M., and R. H. Whitehouse, (1967). Brit Med J. 2, 69. 